\title{
"Ceria"
}

Jurnal Program Studi Pendidikan Anak Usia Dini

ISSN 2301-9905

Volume 8, No. 1, Juli 2018

Fakultas Keguruan dan Ilmu Pendidikan - Universitas Muhammadiyah Tangerang

\section{Upaya Meningkatkan Percaya Diri Melalui Bermain Peran Makro Pada Anak Usia 5-7 Tahun}

\author{
Zahrotunnisa ${ }^{1}$, Yayah Rukhiyah ${ }^{2}$ \\ 1,2Program Studi Pendidikan Guru Pendidikan Anak Usia Dini \\ Fakultas Keguruan dan Ilmu Pendidikan Universitas Muhammadiyah Tangerang \\ Email : ${ }^{1}$ zahrotunnisa022@gmail.com, ${ }^{2}$ yayahrukhiyah@rocketmail.com
}

\begin{abstract}
Abstrak
Penelitian ini bertujuan untuk mengetahui percaya diri melalui bermain peran makro anak usia 5-7 tahun di PAUD Al-Hidayah. Metode yang digunakan adalah penelitian tindakan kelas yang dilakukan sebanyak tiga (3) siklus. Prosedur penelitian ini terdiri dari 4 tahap yaitu perencanaan tindakan, pelaksanaan tindakan, observasi dan refleksi. Metode pengumpulan data yang digunakan dalam penelitian ini adalah observasi, dokumentasi, wawancara dan catatan lapangan. Subjek penelitian ini adalah anak didik kelompok B anak yang mengalami masalah dalam percaya diri anak seperti keyakinan akan kemapuan diri, aktif, kepemimpinan dan inisiatif. Hasil penelitian menunjukan bahwa terjadi peningkatan kemampuan percaya diri anak dengan bermain peran makro. Percaya diri anak pada siklus I terjadi peningkatan pada anak sebesar $50 \%$ anak mulai berani tampil didepan kelas, anak mulai aktif, kepemimpinan dan inisiatif. Pada siklus II adanya peningkatan sebesar $70 \%$, sedangkan pada siklus III mengalami peningkatan sebesar $100 \%$. Dengan demikian dapat disimpulkan bahwa variasi dalam pembelajaran memiliki peranan penting dalam meningkatkan percaya diri anak. Dengan demikian terbukti bahwa bermain peran makro dapat meningkatkan percaya diri pada anak usia 5-7 tahun di PAUD Al-Hidayah kec. Gunung Sindur Kab. Bogor.

Kata Kunci : Percaya Diri, Bermain Peran Makro, Anak Usia 5-7 Tahun
\end{abstract}

\section{Pengantar}

Pendidikan anak usia dini merupakan pendidikan yang dimulai sejak usia 0-6 tahun. Anak merupakan pribadi yang unik maka pada setiap anak memiliki keunikan, kemampuannya serta karakteristik yang berbeda. Sehingga dengan ada karakteristik yang berbeda itulah perlu adanya stimulus yang tepat untuk mengembangkan segala potensinya. Maka sebagai pendidik anak usia dini perlu memahami dan mengembangkan segala aspek perkembangan anak untuk memberikan stimulus yang 
"Ceria"

Jurnal Program Studi Pendidikan Anak Usia Dini

tepat khususnya pada kemampuan kepercayaan diri anak melalui kegiatan bermain peran.

Undang-undang nomor 20 tahun 2003 tentang Sistem Pendidikan Nasional Pasal 1 angka 14 dalam Trianto (2011, h.67) menyatakan bahwa pendidikan anak usia dini adalah suatu upaya pembinaan yang ditunjukkan pada anak sejak lahir sampai dengan usia enam tahun yang dilakukan melalui pemberian rangsangan pendidikan untuk membantu pertumbuhan dan perkembangan jasmani dan rohani agar anak memiliki kesiapan dalam memasuki pendidikan selanjutnya.

PAUD Al-Hidayah memiliki jumlah siswa sebanyak 19 siswa, yang terdiri dari dua kelompok A dan kelompok B. Kelompok A terdiri dari 9 siswa dan kelompok B terdiri dari 10 siswa dengan diajarkan dengan 3 orang guru. Pengajaran di PAUD Al-Hidayah menggunakan metode konvensional sehingga terkadang terjadinya kejenuhan saat belajar. Dan di PAUD Al-Hidayah sebelumnya belum pernah melakukan kegiatan bermain peran makro sehingga butuh metode pengajaran baru yang menyenangkan untuk anak agar anak merasa tidak jenuh dan tetap mendapatkan pengetahuan melalui bermain peran makro.

Menurut Sani (2015, h. 170) bermain peran dilakukan dengan cara mengarahkan peserta didik untuk menirukan suatu aktivitas atau mendramatisasikan situasi, ide, atau karakter khusus. Maka dalam hal ini anak diajak untuk bermain peran makro. Menurut Aricson dalam Adam (2014, h.7) Main peran besar (makro) menggunakan alat dengan ukuran sesungguhnya. Anak dapat menggunakan alat tersebut pada kegiatan mainnya.Anak dapat mengekspresikan ide-idenya dengan "gesture" memerankan seseorang atau sesuatu (mengaduk-aduk pasir dalam mangkuk untuk membuat kue pura-pura) atau dengan obyek (menggunakan kursi sebagai mobil). Bermain peran yang dilakukan anak dengan mempraktikkan sebuah peran atau cerita yang diangkat dengan menggunakan perlengkapan sesuai dengan cerita yang diperankan.

Percaya diri merupakan suatu kemampuan dalam bertindak dimana anak memiliki keyakinan akan kemampuan diri, aktif, kepemimpinan dan inisiatiif. Namun pada kelompok B di PAUD Al-Hidayah dengan jumlah 10 siswa masih ditemukan 6 siswa 
"Ceria"

Jurnal Program Studi Pendidikan Anak Usia Dini

yang memiliki kepercayaan diri rendah, seperti malu untuk ikut berbaris dihalaman kelas jika tidak diantar masuk kebarisan oleh gurunya, masih malu untuk tampil di depan teman-temannya ketika diajak bernyanyi padahal anak sudah hafal nyanyian yang dinyanyikan, tidak mau membaca hafalan doa jika tidak bersama-sama temannya padahal anak sudah hafal, masih ragu-ragu ketika mengerjakan kegiatan yang diberikan padahal anak bisa melakukan kegiatannya sendiri namun masih sering berkata tidak bisa sedangkan anak belum mencoba sehingga guru harus terus memotivasi agar anak tidak selalu bergantung pada gurunya dan mungkin karena terjadinya kebosanan pada anak karena kurangnya pendayagunaan media belajar untuk anak dan kurangnya kegiatan untuk melatih kepercayaan diri anak.

Bermain peran makro dipilih sebagai upaya meningkatkan kepercayaan diri anak karena bermain peran makro sering dilakukan anak ketika bermain namun terkadang kegiatan tersebut belum terarah. Anak-anak pula memiliki imajinasi yang tinggi terkadang benda yang sederhana bisa dibuatnya menjadi fungsi lain yang bisa dimanfaatkan untuk mendukung permainannya sehingga dari situlah bisa dikembangkan untuk meningkatkan percaya diri anak. Tujuan Penelitian Tindakan Kelas ini adalah meningkatkan percaya diri anak melalui kegiatan bermain peran makro di PAUD Al-Hidayah, meningkatkan kemampuan anak dalam berekspresi mengembangkan percaya diri anak.

Manfaat penelitian bagi siswa dapat meningkatnya percaya diri anak, memotivasi anak untuk berani berekspresi. Bagi Guru dapat Mengetahui strategi pembelajaran untuk meningkatkan kepercayaan diri peserta didik, Mengetahui metode yang tepat dan cocok untuk anak sesuai dengan tahap perkembagannya. Bagi Sekolah dapat membuat program pelatihan untuk guru dalam meningkatkan metode bermain peran makro, Adanya pembelajaran bervariasi dan menyenangkan di sekolah. Bagi Peneliti Selanjutnya Mahasiswa memahami bahwa metode - metode mengajar akan efektif melalui metode PTK, Mahasiswa dapat mengetahui kelebihan atau kekurangan metode yang dipilih sebagai bahan pertimbangan dalam menerapkan metode pembelajaran selanjutnya. 
"Ceria"

Jurnal Program Studi Pendidikan Anak Usia Dini

Percaya diri merupakan hal penting yang harus setiap orang miliki untuk keberlagsungan hidupnya dalam menjalan kan segala aktivitasnya. Menurut Angelis dalam Rahayu (2013, h.63) kepercayaan diri merupakan hal yang dengannya anak mampu menyalurkan segala sesuatu yang diketahui dan dikerjakannya. Percaya diri merupakan suatu kemampuan dalam bertindak dimana anak memiliki keyakinan akan kemampuan diri, tidak pasif, kepemimpinan dan inisiatif.

Menurut Madyawati (2016, h.157) bermain peran makro yakni anak berperan sesungguhnya dan menjadi seseorang atau sesuatu. Menurut Sani (2015, h. 166) adapun tahapan dalam bermain peran 1) Guru menyampaikan tujuan pembelajaran, 2) Guru memaparkan permasalahan, 3) Pemilihan pemain peran, 4) Guru dan peserta didik mengatur permainan yang akan dilakukan, 5) Peserta didik melakukan permainan dan diamati peserta didik yang tidak ikut bermain, 6) Guru melakukan evaluasi dan membimbing diskusi terkait permasalahan dan permaianan yang telah dilakukan.

Dengan demikian, melalui kegiatan bermain peran makro dapat meningkatkan percaya diri anak. Karena dengan bermain peran makro dapat meningkatkan keyakinan akan kemampuan diri, aktif, kepemimpinan dan inisiatif yang dimiliki anak.

\section{Metode}

Metode penelitian yang digunakan dalam penelitian ini adalah Penelitian Tindakan Kelas (PTK), dengan subjek penelitian yaitu anak kelompok B (usia 5-7 tahun) di PAUD Al-Hidayah Kec. Gunung Sindur Kab. Bogor. Menurut John Elliot dalam Asip dan Hidayat (2015, h. 42) Penelitian Tindakan Kelas adalah kajian tentang situasi sosial dengan maksud untuk meningkatkan kualitas tindakan yang didalam prosesnya telah dilakukan telaah, diagnosis, perencanaan, pelaksanaan, pemantauan dan evaluasi. Menurut Arikunto, Suhardjono, Supardi (2016, h.129) tujuan dari PTK adalah meningkatkan respon siswa dengan menerapkan metode mengajar baru. Hal ini dilakukan dengan pada bahan atau materi ajar yang sama. Penerapan metode belajar baru dilakukan pada saat guru melakukan kegiatan sehari-hari. Penelitian Tindakan Kelas ini dilakukan sebagi upaya untuk meningkatkan suatu proses pembelajaran 
"Ceria"

Jurnal Program Studi Pendidikan Anak Usia Dini

yang lebih baik tanpa mengubah materi ajar yang akan diberikan hanya metode yang lebih bervariasi dan tidak membosankan bagi anak.

Model yang digunakan dalam penelitian ini adalah model Kemmis dan McTeggart. Model Kemmis dan McTaggart Hidayat dan Asip (2015: 52) dilakukan melalui empat langkah yaitu plan (perencananan), act (tindakan), observe (pengamat), dan reflect (refleksi). Instrumen yang digunakan dalam penelitian ini yaitu berupa teknis nontes berupa lembar observasi yang berupa daftar cheklis $(\sqrt{ })$, dokumentasi, wawancara dan catatan lapangan. Teknik analisis data yang digunakan adalah berupa data kuantitatif dan data kualitatif.

\section{Hasil Dan Pembahasan}

Peningkatan percaya diri anak dalam penelitian ini dilakukan dengan menerapkan kegiatan bermain peran makro dalam tiga siklus, setiap siklus terdiri dari tiga pertemuan. Percaya diri anak diukur berdasarkan empat indikator yaitu keyakinan akan kemampuan diri, aktif, kepemimpinan dan inisiatif.

Berdasarkan pengamatan yang telah dilakukan pada siklus I adanya anak yang memiliki keberanian untuk berbicara dengan temannya yang berperan sebagai pasien walau terkadang ia terlihat bingung hal yang harus dikatakan pada temannya, namun ia terlihat tidak mudah menyerah. Tapi teman yang lainnya yang berperan sebagai pasien belum adanya peningkatan untuk berani berbicara dan belum terlihat adanya inisiatif ketika melakukan permainan. Berdasarkan hasil observasi dan penilaian yang dilakukan dari kegiatan bermain peran makro dengan tema pekerjaan dan subtema dokter terlihat adanya peningkatan yang terjadi, hal ini terlihat pada anak yang sebelumnya belum berkembang menjadi mulai berkembang walaupun belum terlihat peningkatannya secara signifikan. 
"Ceria"

Jurnal Program Studi Pendidikan Anak Usia Dini

Tabel 1

Hasil Observasi Siklus I Percaya Diri Anak

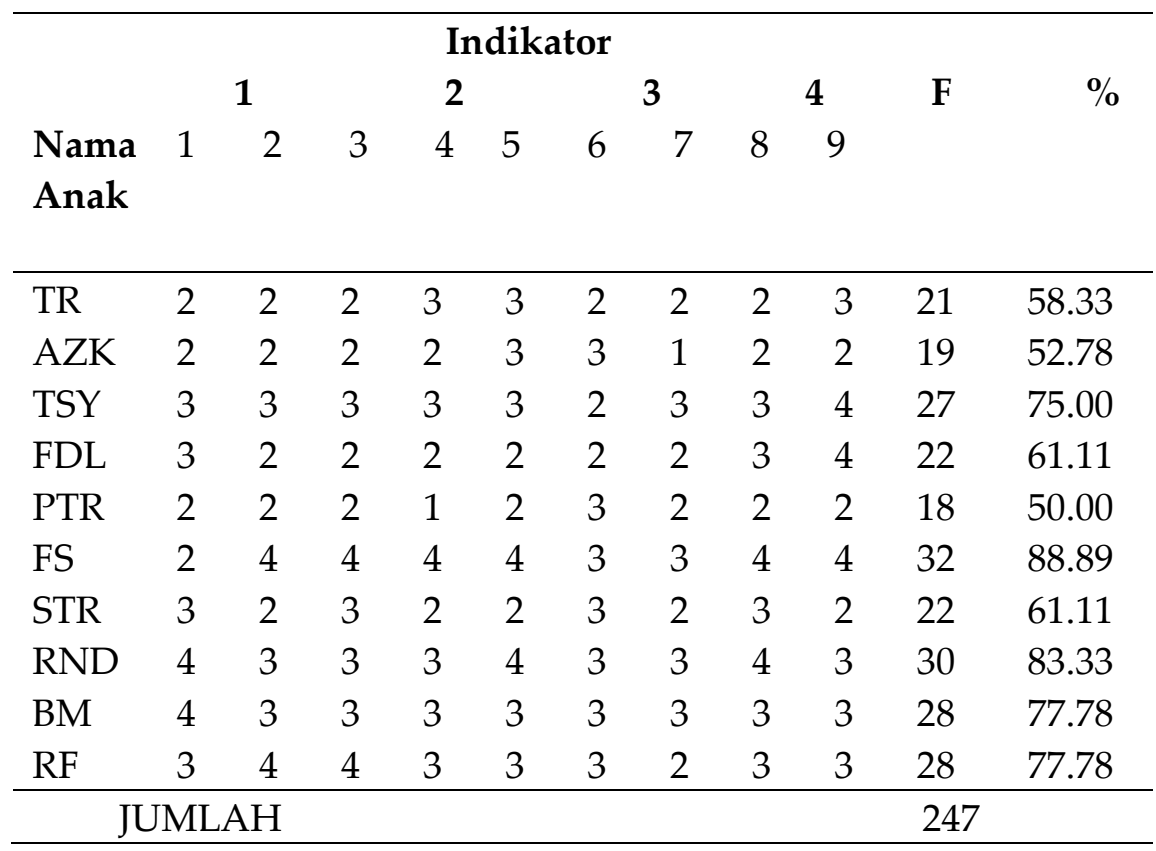

Berdasarkan data yang diperoleh terlihat bahwa 50\% anak mengalami peningkatan pada kegiatan bermian peran makro, 5 dari 10 anak sudah mencapai indikator keberhasilan. Terlihat bahwa sebelum melakukan tindakan anak yang mencapai indikator keberhasilan sebanyak 4 anak, ketika melakukan tindakan meningkat menjadi 5 anak.

Berdasarkan temuan yang dilakukan pada siklus II peneliti Menyiapkan perlengkapan yang digunakan pada kegiatan bermain makro dengan lebih bervariasi dan anak terbiasa memahami aturan yang telah dibuat. Berdasarkan pengamatan yang dilakukan bermain peran makro dengan tema pekerjaan dan subtema pedagang sayur ini anak berani berbicara, mulai terlihat anak tidak perlu motivasi guru untuk dapat berbicara walaupun ada beberapa anak yang masih sedikit dalam mengungkapkan apa yang seharuskan diungkapkan. Berdasarkan hasil observasi dan penilaian yang dilakukan dari kegiatan bermain peran makro sebelumnya maka adanya perbaikan pada siklus II terlihat adanya peningkatan yang terjadi, hal ini terlihat pada anak yang sebelumnya belum berkembang menjadi mulai berkembang, dari mulai berkembang 
"Ceria"

Jurnal Program Studi Pendidikan Anak Usia Dini

meningkat menjadi berkembang sesuai harapan bahkan menjadi berkembang sangat baik.

Tabel 2

Hasil Observasi Siklus II Percaya Diri Anak

\begin{tabular}{|c|c|c|c|c|c|c|c|c|c|c|c|}
\hline \multirow{3}{*}{$\begin{array}{l}\text { Nama } \\
\text { Anak }\end{array}$} & \multicolumn{9}{|c|}{ Indikator } & \multirow{3}{*}{ F } & \multirow{3}{*}{$\%$} \\
\hline & \multicolumn{2}{|c|}{1} & \multicolumn{3}{|c|}{2} & \multicolumn{2}{|c|}{3} & \multicolumn{2}{|c|}{4} & & \\
\hline & 1 & 2 & 3 & 4 & 5 & 6 & 7 & 8 & 9 & & \\
\hline TR & 3 & 3 & 2 & 3 & 4 & 3 & 2 & 3 & 4 & 27 & 75.00 \\
\hline AZK & 3 & 2 & 3 & 2 & 3 & 3 & 2 & 2 & 3 & 23 & 63.89 \\
\hline TSY & 3 & 3 & 3 & 3 & 3 & 3 & 3 & 3 & 4 & 28 & 77.78 \\
\hline FDL & 4 & 3 & 3 & 4 & 2 & 3 & 2 & 3 & 4 & 28 & 77.78 \\
\hline PTR & 3 & 2 & 3 & 2 & 2 & 3 & 2 & 3 & 2 & 22 & 61.11 \\
\hline FS & 3 & 4 & 4 & 4 & 4 & 3 & 3 & 4 & 4 & 33 & 91.67 \\
\hline STR & 3 & 2 & 3 & 2 & 2 & 3 & 3 & 3 & 4 & 25 & 69.44 \\
\hline RND & 4 & 4 & 3 & 3 & 4 & 3 & 3 & 4 & 3 & 31 & 86.11 \\
\hline $\mathrm{BM}$ & 4 & 3 & 4 & 3 & 3 & 3 & 3 & 3 & 3 & 29 & 80.56 \\
\hline $\mathrm{RF}$ & 4 & 4 & 4 & 3 & 3 & 3 & 3 & 3 & 4 & 31 & 86.11 \\
\hline \multicolumn{11}{|c|}{ JUMLAH } & 277 \\
\hline
\end{tabular}

Berdasarkan data yang diperoleh terlihat bahwa $70 \%$ anak dapat meningkat kemampuan percaya diri anak melalui kegiatan bermain peran makro. Pada siklus II terlihat peningkatannya secara signifikan. Terlihat bahwa sebelum melakukan tindakan dan siklus I anak yang mencapai indikator keberhasilan sebanyak 5 anak, ketika melakukan tindakan pada siklus II meningkat menjadi 7 anak.

Berdasarkan pengamatan yang telah dilakukan pada siklus III dengan tema bermain peran makro sebagai guru dan murid kali ini permainan sudah tenang karena anakanak sudah faham cara bermain dan mentaati peraturan yang telah dibuat dan disepakati. BM pun sudah berani menegur temannya jika tidak memperhatikannya. Sehingga hasil observasi dan penilaian yang dilakukan dari kegiatan bermain peran makro dengan tema pekerjaan dan subtema guru dan murid terlihat adanya peningkatan yang terjadi, hal ini terlihat pada anak yang sebelumnya belum berkembang menjadi mulai berkembang, dari mulai berkembang meningkat menjadi berkembang sesuai harapan bahkan menjadi berkembang sangat baik. 
Tabel 3

Hasil Observasi Siklus III Percaya Diri Anak

\begin{tabular}{|c|c|c|c|c|c|c|c|c|c|c|c|}
\hline \multirow{3}{*}{$\begin{array}{l}\text { Nama } \\
\text { Anak }\end{array}$} & \multicolumn{9}{|c|}{ Indikator } & \multirow{3}{*}{ F } & \multirow{3}{*}{$\%$} \\
\hline & \multicolumn{2}{|c|}{1} & \multicolumn{3}{|c|}{2} & \multicolumn{2}{|c|}{3} & \multicolumn{2}{|c|}{4} & & \\
\hline & 1 & 2 & 3 & 4 & 5 & 6 & 7 & 8 & 9 & & \\
\hline TR & 3 & 3 & 3 & 3 & 4 & 3 & 2 & 3 & 4 & 28 & 77.78 \\
\hline AZK & 3 & 3 & 3 & 3 & 3 & 4 & 2 & 3 & 3 & 27 & 75.00 \\
\hline TSY & 4 & 3 & 3 & 3 & 3 & 3 & 3 & 3 & 4 & 29 & 80.56 \\
\hline FDL & 4 & 3 & 3 & 4 & 3 & 3 & 3 & 3 & 4 & 30 & 83.33 \\
\hline PTR & 3 & 3 & 3 & 3 & 3 & 4 & 3 & 3 & 3 & 28 & 77.78 \\
\hline FS & 3 & 4 & 4 & 4 & 4 & 3 & 4 & 4 & 4 & 34 & 94.44 \\
\hline STR & 4 & 3 & 3 & 4 & 3 & 4 & 3 & 3 & 4 & 31 & 86.11 \\
\hline RND & 4 & 4 & 3 & 4 & 4 & 3 & 3 & 4 & 3 & 32 & 88.89 \\
\hline BM & 4 & 3 & 4 & 3 & 3 & 4 & 3 & 3 & 3 & 30 & 83.33 \\
\hline RF & 4 & 4 & 4 & 3 & 3 & 4 & 3 & 4 & 4 & 33 & 91.67 \\
\hline \multicolumn{11}{|c|}{ JUMLAH } & 302 \\
\hline
\end{tabular}

Berdasarkan data yang diperoleh terlihat bahwa $100 \%$ anak sudah mengalami peningkatan percaya diri anak melalui bermain peran makro. Pada siklus II terlihat peningkatannya secara signifikan. Terlihat bahwa sebelum melakukan tindakan dan siklus I anak yang mencapai indikator keberhasilan sebanyak 5 anak, ketika melakukan tindakan pada siklus II meningkat menjadi 7 anak dan pada siklus III sebayak 10 anak.

Berdasarkan paparan hasil data terkait percaya diri anak di atas dapat diketahui bahwa kegiatan bermain peran makro dapat meningkatkan percaya diri anak. Dengan bermain peran makro anak memiliki keyakinan akan kemampuan dirinya, anak menjadi lebih berani berekspresi.

\section{Kesimpulan}

Berdasarkan hasil penelitian dan pembahasan yang telah dilakukan, maka dapat disimpulkan bahwa bermain peran makro yang telah dilakukan di PAUD Al-Hidayah dapat meningkatkan percaya diri anak. Ini terlihat pada kondisi awal yang memiliki percaya diri rendah sebanyak 6 anak. Setelah melakukan tindakan dengan bermain peran makro meningkat menjadi 5 anak. Adapun pada siklus I terjadi peningkatan 
"Ceria"

Jurnal Program Studi Pendidikan Anak Usia Dini

pada anak sebesar $50 \%$ anak mulai berani tampil didepan kelas, anak mulai aktif, kepemimpinan dan inisiatif. Pada siklus II adanya peningkatan sebesar $70 \%$, sedangkan pada siklus III mengalami peningkatan sebesar $100 \%$. Pada kondisi awal anak yang mencapai indikator keberhasilan sebanyak 4 anak, siklus I anak yang mencapai indikator keberhasilan sebanyak 5 anak, pada siklus II sebanyak 7 anak dan pada siklus III sebanyak 10 anak yang telah mencapai inikator keberhasilan. Terbukti dari hipotesis penelitian bahwa percaya diri anak usia 5-7 tahun dapat meningkat melalui bermain peran makro. Dengan bermain peran makro mengalami peningkatan secara signifikan dalam kemampuan percaya diri anak.

Berdasarkan hasil penelitian yang disimpulkan di atas, beberapa hal yang dapat ditindak lanjuti. Bagi Siswa dengan menggunakan kegiatan bermain peran makro dapat meningkatkan percaya diri pada anak, anak diajak bermain sehingga memotivasi anak untuk berani berekspresi. Bagi Guru diharapkan mengetahui strategi pembelajaran untuk meningkatkan percaya diri anak. Guru juga mampu mengetahui metode yang tepat dan cocok untuk anak yang sesuai dengan tahap perkembangannya. Bagi sekolah dapat membuat program pelatihan untuk guru dalam meningkatkan metode bermain peran makro dan adanya pembelajaran bervariasi dan menyenangkan ketika disekolah. Bagi Peneliti Selanjutny memahami bahwa metode metode mengajar akan efektif melalui metode PTK. Dan mahasiswa dapat mengetahui kelebihan atau kekurangan metode yang dipilih sebagai bahan pertimbangan dalam menerapkan metode pembelajaran selanjutnya

\section{Daftar Acuan}

Adam, Siska R. (2014). Hubungan Antara Bermain Peran Dengan Perkembangan Sosial pada Anak Kelompok B TK Negeri Pembina Ki Hadjar Dewantoro Kecamatan Kota Selatan Kota Gorontalo. Fakultas Ilmu Pendidikan. Gorontalo: Universitas Negeri Gorontalo. Artikel jurnal. Diakses dari http://kim.ung.ac.id/index.php/KIMFIP/article/download/6637/6533

Arikunto, Suharsimi, Suhardjono, \& Supardi. (2016). Penelitian Tindakan Kelas. Jakarta: Bumi Aksara. 
"Ceria”

Jurnal Program Studi Pendidikan Anak Usia Dini

Hidayat, Syarif \& Asip. (2015). Penelitian Tindakan Kelas. Tangerang: Pustaka Mandiri.

Madyawati, Lilis. (2016). Strategi Pengembangan Bahasa pada Anak. Jakarta: Kencana.

Rahayu, Aprianti Y. (2013). Menumbuhkan Kepercayaan Diri Melalui Kegiatan Bercerita. Jakarta: PT Indeks.

Sani, Ridwan A. (2015). Inovasi Pembelajaran. Jakarta: Bumi Aksara.

Trianto. (2011). Desain Pengembangan Pembelajaran Tematik. Jakarta: Kencana. 